\title{
Conglomeromonas largomobilis gen. nov., sp. nov., a Sodium-Sensitive, Mixed-Flagellated Organism from Fresh Waters
}

\author{
V. B. D. SKERMAN,* L. I. SLY, AND MARY-LOU WILLIAMSON \\ Department of Microbiology, University of Queensland, St. Lucia 4067, Brisbane, Australia
}

\begin{abstract}
A gram-negative rod-shaped organism which exhibits unicellular and multicellular phases of growth is described. Unicellular-phase cells are motile and have mixed flagellation, with a single polar flagellum and 1 to 10 lateral flagella which are easily distinguishable from the polar flagellum by differences in thickness and wavelength. Multicellular conglomerates arise from single cells which lose motility, become optically refractile, and reproduce by multiplanar centripetal septation. Conglomerate formation is enhanced by the presence of sodium ions. Under suitable conditions conglomerates dissociate into single cells, which produce water-clear colonies in which there are initially only a few sluggishly motile unicellular-phase cells. A new genus, Conglomeromonas gen. nov., with the single species Conglomeromonas largomobilis sp. nov. is proposed for these strains, which were isolated from fresh waters. Two subspecies, $C$. largomobilis subsp. largomobilis subsp. nov. (type strain, UQM 2041) and $C$. largomobilis subsp. parooensis subsp. nov. (type strain, UQM 2042), are proposed.
\end{abstract}

In the course of a study of the microflora of fresh waters, lake water agar (LWA) plates surface inoculated with 1 drop of water and then air dried were incubated for periods of up to 3 weeks. Most isolations were made with a micromanipulator (20) within the first $24 \mathrm{~h}$. Subsequent incubation was continued to study population interactions and production of fruiting structures of actinomycetes, myxobacteria, and fungi.

Multicellular bodies (conglomerates) (see Fig. $1 \mathrm{~A}$ and B) reminiscent of the growth of Dermatophilus and Geodermatophilus developed on some plates. Transferred by micromanipulation to fresh LWA, each conglomerate transformed after periods of 4 to $8 \mathrm{~h}$ to a number of actively motile cells containing highly refractile granules (Fig. 1C and D). There was no evidence of any residue from the conglomerate, as observed under phase-contrast microscopy. At this stage, the motile cells had a striking resemblance to cells of Beijerinckia species. After continued incubation these cells produced initially waterclear colonies in which phase-dense oval cells meandered to and fro in a copious optically clear fluid. Single cells selected and cultured on LWA produced this colony form. After prolonged incubation a few of the multicellular forms appeared among the dense population.

Suspecting that the formation of the multicelled aggregates on the original plates may have been due to drying, we inoculated cells onto LWA containing $2 \% \mathrm{NaCl}$ to remove some of the free water. On this medium individual cells became quite refractile and then divided internally, first by transverse wall formation to give multicelled elongated forms of four to eight cells and then in different planes to produce the large multicellular conglomerates originally observed on the primary isolation plates. These cultures, which were isolated from widely separated locations, are the subject of this paper.

\section{MATERIALS AND METHODS}

Bacterial strains. The strains of bacteria used are listed in Table 1.

Isolation. A brief outline of the method of isolation is given above. When removed by micromanipulation, multicellular forms were rubbed over a LWA surface until it was optically clear of contaminants. Plates were incubated until the characteristic transformation occurred, and then single cells were separated with a microloop (20) and allowed to develop into microcolonies, which were transferred on supporting agar blocks to culture tubes. Cultures were then inoculated to LWA and lakewater salt agar (LWSA) to ensure that the phenomenon was reproducible.

The growth of these cultures was compared with that of Dermatophilus, Geodermatophilus, and Blastococcus on LWA and LWSA.

Media. All media were sterilized by autoclaving at $121^{\circ} \mathrm{C}$ for $15 \mathrm{~min}$. LWA was prepared as previously described (5). LWSA was prepared by adding 0.5, 1.0, $1.5,2.0$, or $5 \%$ (wt/vol) $\mathrm{NaCl}$ to $\mathrm{LWA}$ before autoclaving. Peptone-yeast extract (PYE) broth contained 1\% peptone (type L37; Oxoid Ltd., London, England), 1\% yeast extract (type L21; Oxoid), and $0.5 \% \mathrm{NaCl}$; the $\mathrm{pH}$ of this medium was adjusted to 7.2. Peptone-yeast 
TABLE 1. Strains used in this study

\begin{tabular}{|c|c|c|}
\hline $\begin{array}{c}\text { Laboratory } \\
\text { no. }{ }^{a}\end{array}$ & Received as: & Source ${ }^{b}$ \\
\hline $\begin{array}{l}\text { UQM } 22 \\
\text { UQM } 530 \\
\text { UQM } 858^{\mathrm{T}} \\
\text { UQM } 1134^{\mathrm{T}} \\
\text { UQM } 1288^{\mathrm{T}}\end{array}$ & $\begin{array}{l}\text { Aeromonas hydrophila } \\
\text { Dermatophilus congolensis M6444 } \\
\text { Morococcus cerebrosus } \\
\text { Plesiomonas shigelloides NCIB } 9242 \\
\text { Geodermatophilus obscurus ATCC } \\
\quad 25078\end{array}$ & $\begin{array}{l}\text { Delft } \\
\text { Lechevalier } \\
\text { Harper } \\
\text { NCIB } \\
\text { ATCC }\end{array}$ \\
\hline UQM $2041^{\mathrm{T}}$ & Original isolate & $\begin{array}{l}\text { Freshwater; Somerset Dam, Queens- } \\
\text { land, Australia (latitude } 27^{\circ} 05^{\prime} \text {; } \\
\text { longitude } 152^{\circ} 35^{\prime} \text { ) }\end{array}$ \\
\hline UQM $2042^{\mathrm{T}}$ & Original isolate & $\begin{array}{l}\text { Freshwater; Eulo-Yowah branch of } \\
\text { Paroo Channel, Queensland, Aus- } \\
\text { tralia (latitude } 28^{\circ} 08^{\prime} \text {; longitude } \\
144^{\circ} 37^{\prime} \text { ) }\end{array}$ \\
\hline UQM 2043 & Original isolate & $\begin{array}{l}\text { Littoral zone mud below Cooby } \\
\text { Dam, Queensland, Australia (lati- } \\
\text { tude } 27^{\circ} 23^{\prime} \text {; longitude } 151^{\circ} 57^{\prime} \text { ) }\end{array}$ \\
\hline UQM $2269^{\mathrm{T}}$ & Blastococcus aggregatus B15 & Rheinheimer \\
\hline
\end{tabular}

${ }^{a}$ UQM, Culture Collection, Department of Microbiology, University of Queensland, Brisbane, Australia.

${ }^{b}$ ATCC, American Type Culture Collection, Rockville, Md.; Delft, Laboratory of Microbiology, Delft, The Netherlands; Harper, J. Harper, Royal Brisbane Hospital, Brisbane, Australia; Lechevalier, H. Lechevalier, Institute of Microbiology, Rutgers State University, Brunswick, N.J.; NCIB, National Collection of Industrial Bacteria, Aberdeen, Scotland; Rheinheimer, G. Rheinheimer, Institute für Meereskunde und Hygiene-Institut der Universităt Kiel, Kiel, West Germany.

extract agar (PYEA) was prepared by solidifying PYE broth with $1.5 \%$ agar (Davis). Glucose-ammonium sulfate agar, $0.1 \%$ peptone agar, nitrogen-free media, autotrophic media, and mineral salts media supplemented with glucose, phenol, citrate, and alkylamines have been described previously (19).

Media with water activities equivalent to that of LWSA containing $2 \% \mathrm{NaCl}$ were prepared by adding $\mathrm{NaCl}, \mathrm{CaCl}_{2}$, glycerol, or sucrose in the amounts indicated by Scott (17).

Photography. Microcolonies were photographed after incubation at $22^{\circ} \mathrm{C}$ on plates of LWA and LWSA containing $2 \% \mathrm{NaCl}$ by using Olypmus $\times 10, \times 40$, and $\times 100$ objectives or a Leitz PHACO $\times 32$ phase-contrast objective, an Olypmus PM-6 camera attachment, and a type EMM-6 exposure meter. Kodak Plus-X Pan film and a green filter were used.

Morphology and staining reactions. Cell size was determined by phase-contrast microscopy of microcolonies grown on LWA and PYEA. Cultures were Gram stained by the Bartholomew method (19) and were examined for capsules by the dry India ink film method (3) and for sudanophilic inclusions by Sudan black B staining (3). The presence of poly- $\beta$-hydroxybutyrate inclusions was confirmed by extraction and purification, using the method of Forsyth et al. (4). Evidence of motility was obtained by direct phasecontrast microscopy of the microcolonies. Cells were examined for flagella by electron microscopy.

Electron microscopy. All specimens were examined with a Philips model EM 300 transmission electron microscope. Cells were examined for flagella after rotary shadowing at a $10^{\circ}$ angle with $5 \mathrm{~nm}$ of platinum in a Balzers high-vacuum coating unit (model BAE 120; Balzers AG, Balzers, Furstentum, Liechtenstein). Thin sections were cut with a Reichert model OMU 2 microtome from cells fixed by the ruthenium red method of Luft (13) and embedded in Polarbed 812 epoxy resin (Polaron, Watford, England). Sections were stained for $30 \mathrm{~min}$ in $\mathbf{4 . 0 \%}$ uranyl acetate and for $2 \mathrm{~min}$ in $1.2 \%$ lead acetate.

Biochemical and physiological tests. Unless otherwise stated, test media were inoculated from 48-h-old growth of each strain grown on PYEA at $28^{\circ} \mathrm{C}$ and then incubated at $28^{\circ} \mathrm{C}$.

The ability of the isolates to grow on LWA, PYEA, $0.1 \%$ peptone agar, and glucose-ammonium sulfate agar was tested. Growth in the presence of 0.5 to $5.0 \%$ salt was examined on LWSA. The utilization of glucose, phenol, citrate, or alkylamine in mineral salts (19), the ability to fix nitrogen in nitrogen-free liquid media supplemented with glucose, mannitol, or sucrose (19), and the ability to grow autotrophically with ammonium, nitrite, thiosulfate, or ferrous ions were tested (19). Growth at different temperatures was tested in PYE broth in a gradient temperature incubator (Lindner and May, Brisbane, Australia) over a 2week period. Anaerobic growth was observed on PYEA plates after $72 \mathrm{~h}$ of incubation in an anaerobic jar with an atmosphere containing $10 \% \mathrm{CO}_{2}$ and $90 \%$ $\mathrm{H}_{2}$.

Growth on PYEA for $24 \mathrm{~h}$ was used to test for catalase (19), oxidase (10), and aminopeptidase (2). Tests for indole production from peptone water, $\mathrm{H}_{2} \mathrm{~S}$ from peptone-cystine sulfate medium, urease, and phenylalanine deaminase and the methyl red and Voges-Proskauer tests were carried out (19). The method of Thornley (22) was used to detect arginine dihydrolase activity, and the method of Holding and Collee (8) was used for phosphatase. Deoxyribonuclease activity was assessed by using DNase agar (Oxoid). The deposition of iron on ferric ammonium citrate agar (19) was tested. Hemolysis was assessed in blood agar base (type CM55; Oxoid) supplemented with 5\% defibrinated horse blood (Commonwealth Serum Laboratories, Melbourne, Australia). 
The nitrate reduction test and the Hugh-Leifson oxidation-fermentation test were carried out as described by Skerman (19). Acid production from $1 \%$ (wt/vol) carbohydrates and $1 \%$ (wt/vol) alcohols in Hayward basal medium (7) was examined at 7 days and up to 4 weeks. The utilization of malonate and citrate (Christensen and Simmon methods) was also determined (19), as were the ability to oxidize ethanol (19) and the ability to oxidize gluconate (6).

The hydrolysis of cellulose, starch, gelatin, chitin (using commercially prepared chitin), and alginate, the digestion of carrot plugs, and the liquefaction of Loeffler inspissated serum were tested as previously described (19). Esculin, tributyrin, and Tween 80 hydrolyses were determined by the methods of Sneath (21), Holding and Collee (8), and Sierra (18), respectively. Casein hydrolysis was tested in Oxoid nutrient agar supplemented with $20 \%$ skim milk.

Determination of DNA base composition. Deoxyribonucleic acid (DNA) was purified and analyzed as previously described (5).

\section{RESULTS}

Microcolony morphology. In the multicellular (conglomerate) phase (Fig. 1A, B, and G), the microcolonies which we observed were morphologically unlike microcolonies of any previously described microorganism except Dermatophilus congolensis, Geodermatophilus obscurus (12), Blastococcus aggregatus (1), and the recently described Morococcus cerebrosus (11). In the unicellular phase on LWA, all three of our strains produced initially similar water-clear microcolonies in which the relatively few cells present meandered to and fro in an abundance of optically clear fluid (Fig. 1E). As the population developed, the colonies enlarged, until ultimately the proportion of slime to cells was reduced to a level common to most bacteria. Conglomerates developed from single cells which lost motility, became optically refractile, and divided internally, first by transverse wall formation to produce multicellular elongated forms of four to eight cells (Fig. 1F) and then in different planes. Some aberrant cells were also produced initially, but they rarely developed further.

Macrocolony morphology. (i) Colonies on LWA. Colonies grown on LWA for $72 \mathrm{~h}$ at $28^{\circ} \mathrm{C}$ were 1 to $2 \mathrm{~mm}$ in diameter, colorless, translucent, low convex, and round with an entire edge and smooth surface, and they readily coalesced. The intracellular matrix was water clear, of low viscosity, and easily emulsified. The cell populations were mainly in the motile phase, but some colonies composed of conglomerates were also produced, particularly when colonies were well separated and the agar plates were well dried. The latter usually had the same diameter as the colonies of the unicellular forms, but occasionally they were larger. These colonies were dry, colorless, opaque, raised, and round with a rough furrowed surface and irregular edge (Fig.
1G). Each conglomerate could be moved intact.

(ii) Colonies on LWSA containing $2 \% \mathrm{NaCl}$. Development of conglomerates was enhanced on LWSA containing $2 \%(0.35 \mathrm{M}) \mathrm{NaCl}$. The appearance of these conglomerates was the same as it was on LWA, except that they had a pale pink color. Development was also enhanced by other sodium salts (viz., $\mathrm{Na}_{2} \mathrm{SO}_{4}$ and $\mathrm{NaNO}_{3}$ ) when they were incorporated into the medium at a concentration of $0.35 \mathrm{M} \mathrm{Na}^{+}$. There was no enhancement of conglomerate development by $\mathrm{LiCl}, \mathrm{KCl}, \mathrm{CaCl}$, or $\mathrm{MgCl}_{2}$ at the same metal ion concentration or by media adjusted with $\mathrm{CaCl}_{2}$, glycerol, or sucrose to a water activity equivalent to that of LWSA containing $2 \% \mathrm{NaCl}$.

(iii) Colonies on PYEA. Colonies of strains UQM 2041 ${ }^{\mathrm{T}}$ (type strain) and UQM 2043 grown for $72 \mathrm{~h}$ at $28^{\circ} \mathrm{C}$ were $2 \mathrm{~mm}$ in diameter, cream to buff in color, opaque, low convex, and round with an entire edge and smooth surface. Growth was mucoid and easily emulsified. On the other hand, the growth of strain UQM $2042^{\mathrm{T}}$ was apricot colored and, although concentrated growth was similar in appearance and consistency to growth of the other strains, individual colonies only developed in the conglomerate form. This strain also developed predominantly in the conglomerate form on $\mathrm{NaCl}$-free peptoneyeast extract agar.

Growth in PYE broth. Growth in PYE broth consisted of a delicate pellicle and a sediment of conglomerates; there was no turbidity in undisturbed tubes.

Cellular morphology. In the unicellular phase, cells of the three isolates were gram negative, nonsporing, noncapsulated, and rod shaped with rounded or tapered ends and a straight or slightly curved axis; these cells were arranged singly or in pairs and contained poly- $\beta$-hydroxybutyrate inclusions. The dimensions of the cells are given in Table 2. Most individual cells were motile and exhibited mixed flagellation, with a polar flagellum and 1 to 10 distinctive lateral flagella of different thickness and wavelength (Fig. 2A and B). The polar flagellum had a waveform with a wavelength of $1.62 \mu \mathrm{m}$ and an amplitude of $198 \mathrm{~nm}$; the narrower lateral flagella had a wavelength of $0.59 \mu \mathrm{m}$ and an amplitude of $110 \mathrm{~nm}$.

Structure of conglomerate forms. Ultrathin sections of the multicellular conglomerate forms examined by electron microscopy showed that reproduction occurred by centripetal growth of the cell wall (Fig. 3A and B). Cell wall development in different planes gave rise to the final conglomerate appearance (Fig. 3A). The units of the conglomerates were surrounded by and bound together by laminated layers which stained with ruthenium red and were most likely acidic polysaccharide in nature (Fig. $3 \mathrm{C}$ ). 

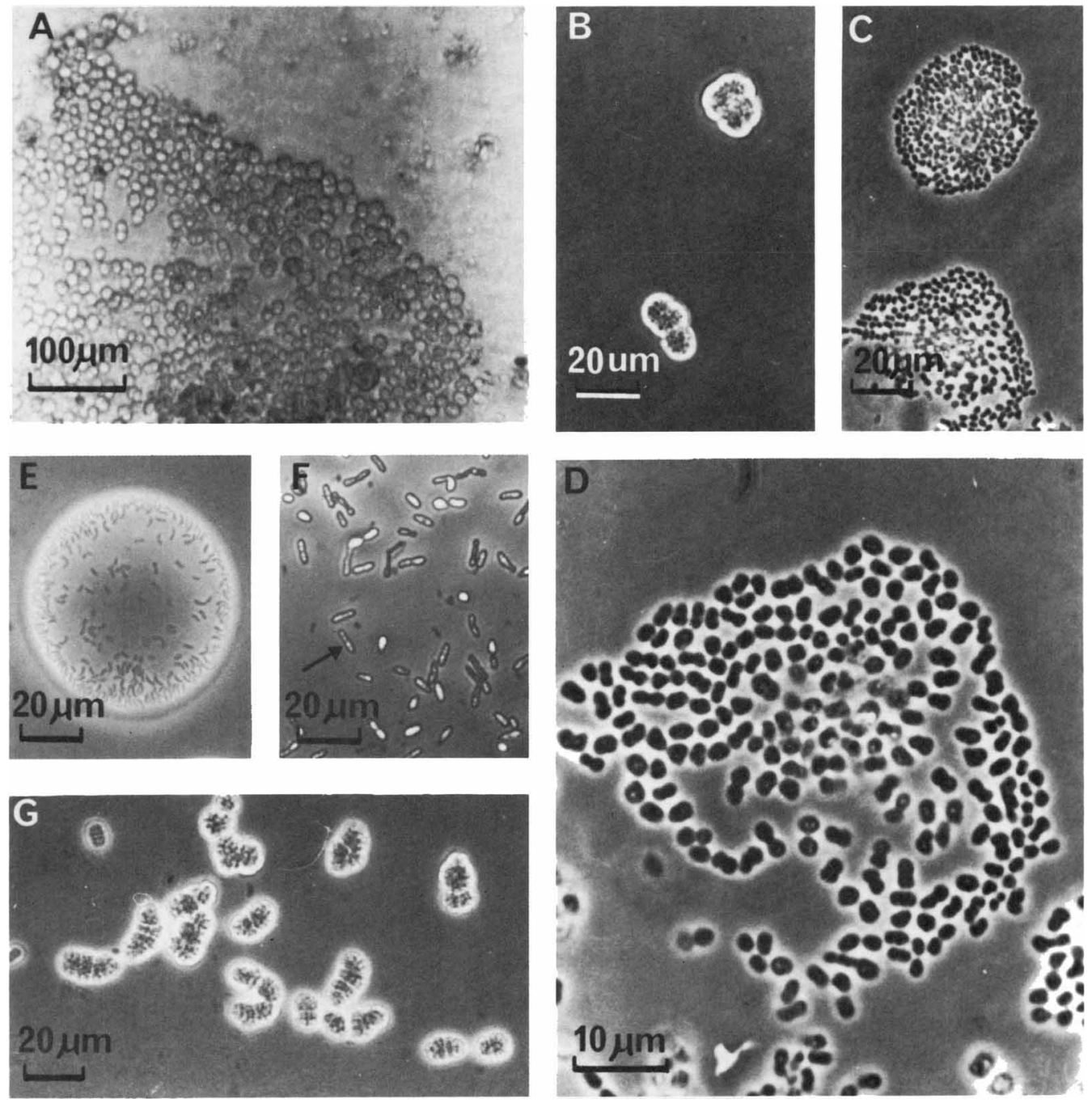

FIG. 1. Photomicrographs of $C$. largomobilis strain UQM $2042^{\mathrm{T}}$. (A) Conglomerates on an 8-day-old LWA isolation plate. (B) Separated conglomerates on LWA. (C) Dissociation of the conglomerates shown in (B) into single cells after $10 \mathrm{~h}$ of incubation. (D) Single cells from a dissociated conglomerate showing poly- $\beta$ hydroxybutyrate inclusions. (E) Two-day-old colony of unicellular-phase cells on LWA, showing the sparse distribution of motile cells in an abundance of optically clear fluid. (F) Early transformation of unicellular-phase cells to multicellular-phase cells, showing increased optical refractility and cross wall development (arrow). (G) Seven-day-old conglomerates on LWSA containing $2 \% \mathrm{NaCl}$.

Growth and nutrition. All strains grew on LWA and LWSA containing 0.5 and $2 \% \mathrm{NaCl}$ but not on LWSA containing $5 \% \mathrm{NaCl}$. Growth also occurred on PYEA, $0.1 \%$ peptone agar, and glucose-ammonium sulfate agar and in citratemineral salts medium. No growth occurred in phenol- or alkylamine-mineral salts medium, in nitrogen-free media supplemented with glucose, sucrose, or mannitol, or under autotrophic conditions with ammonium sulfate, sodium nitrate, sodium thiosulfate, or ferrous sulfate. Anaerobic growth occurred on PYEA. The optimal growth temperature was $28^{\circ} \mathrm{C}$.
Biochemical and physiological properties. The isolates produced catalase, oxidase, aminopeptidase, phosphatase, deoxyribonuclease, and urease; nitrate was reduced to nitrite; citrate and malonate were utilized; and iron was deposited on ferric ammonium citrate agar.

Starch and Tween 80 were hydrolyzed by all strains, but chitin, alginate, cellulose, gelatin, tributyrin, and casein were not. None of the strains was hemolytic or produced phenylalanine deaminase, arginine dihydrolase, indole, or $\mathrm{H}_{2} \mathrm{~S}$. Carrot plugs were not digested, and no liquefaction of Loeffler inspissated serum oc- 
TABLE 2. Characteristics differentiating the subspecies of $C$. largomobilis gen. nov., sp. nov.

\begin{tabular}{|c|c|c|c|}
\hline \multirow{2}{*}{ Character } & \multicolumn{2}{|c|}{$\begin{array}{l}\text { C. largomobilis } \\
\text { subsp. largomobilis }\end{array}$} & \multirow{2}{*}{$\begin{array}{c}\text { C. largomobilis } \\
\text { subsp. parooensis } \\
\text { UQM } 2042\end{array}$} \\
\hline & UQM 2041 & UQM 2043 & \\
\hline \multicolumn{4}{|l|}{ Cell size $(\mu \mathrm{m})$} \\
\hline Grown on LWA & 1 to 1.5 by 3 to 4.5 & 1 to 1.5 by 3 to 4.5 & $\begin{array}{l}1 \text { to } 1.5 \text { by } 2 \text { to } 3 \\
\text { (occasional } \\
\text { cells } 1.5 \text { to } 2.25 \\
\text { by } 4.5 \text { ) }\end{array}$ \\
\hline Grown on PYEA & 0.75 to 1 by 3 to 4.5 & 0.75 to 1 by 3 to 4.5 & 1 to 1.5 by 1.5 \\
\hline $\begin{array}{l}\text { Colony color, } \\
\text { (on PYEA) }\end{array}$ & Cream-buff & Cream-buff & Apricot \\
\hline Growth temp range $\left({ }^{\circ} \mathrm{C}\right)$ & 14 to 43.5 & 13 to 40.7 & 10 to 37 \\
\hline $\begin{array}{l}\text { Hydrolysis of } \\
\text { aesculin }\end{array}$ & + & + & - \\
\hline Catalase & Weak & Weak & Strong \\
\hline Phosphatase & Weak & Weak & Strong \\
\hline \multicolumn{4}{|l|}{ Acid produced from: } \\
\hline Glycerol & + & + & - \\
\hline Sorbitol & + & + & - \\
\hline Cellobiose & $(+)^{a}$ & $(+)$ & + \\
\hline Mannose & - & - & + \\
\hline Rhamnose & - & - & + \\
\hline Inositol & - & - & $(+)$ \\
\hline Lactose & - & - & $(+)$ \\
\hline DNA $(\mathrm{mol} \% \mathrm{G}+\mathrm{C})$ & $70.0 \pm 0.3$ & $70.3 \pm 0.8$ & $67.2 \pm 0.8$ \\
\hline
\end{tabular}

${ }^{a}+$, Positive reaction; - , negative reaction; $(+)$, late positive reaction (4 weeks).

curred. Neither ethanol nor gluconate was oxidized.

Carbohydrate metabolism was fermentative in the Hugh-Leifson test. A late but weak methyl red reaction was recorded after 10 days, and the Voges-Proskauer reaction was negative. All strains produced acid but no gas from galactose, glucose, mannitol, and melibiose. No acid was produced from adonitol, amygdalin, D-arabinose, arabitol, dextrin, dulcitol, erythritol, etha- nol, fructose, inulin, maltose, melezitose, raffinose, D-ribose, salicin, L-sorbose, starch, sucrose, trehalose, or xylose. The results of differential acid reactions with glycerol, sorbitol, cellobiose, mannose, rhamnose, inositol, and lactose are shown in Table 2.

Growth of $B$. aggregatus on LWA and LWSA. When $B$. aggregatus was cultured on LWA, it produced microcolonies in which single cells were closely aggregated in a monolayer in the
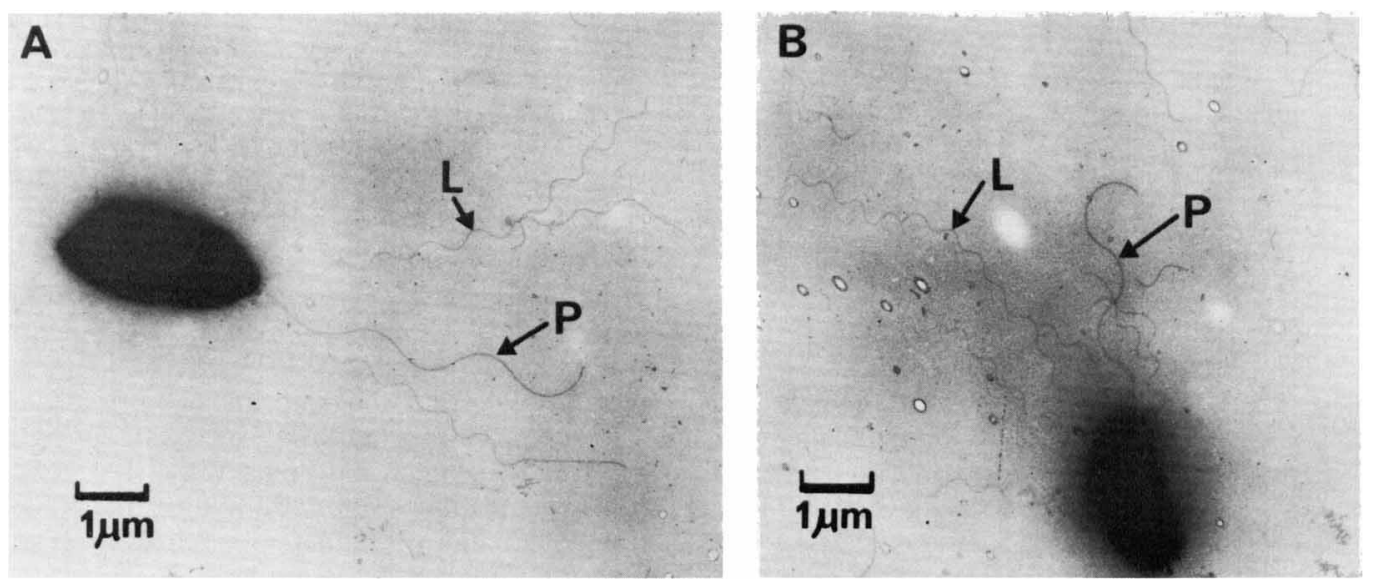

FIG. 2. Electron micrographs of platinum-shadowed unicellular-phase cells of $C$. largomobilis, showing examples of mixed flagellation with distinctive polar $(\mathrm{P})$ and lateral $(\mathrm{L})$ flagella of different thicknesses and wavelengths. (A) Strain UQM 2041 ${ }^{\mathrm{T}}$. (B) Strain UQM $2042^{\mathrm{T}}$. 

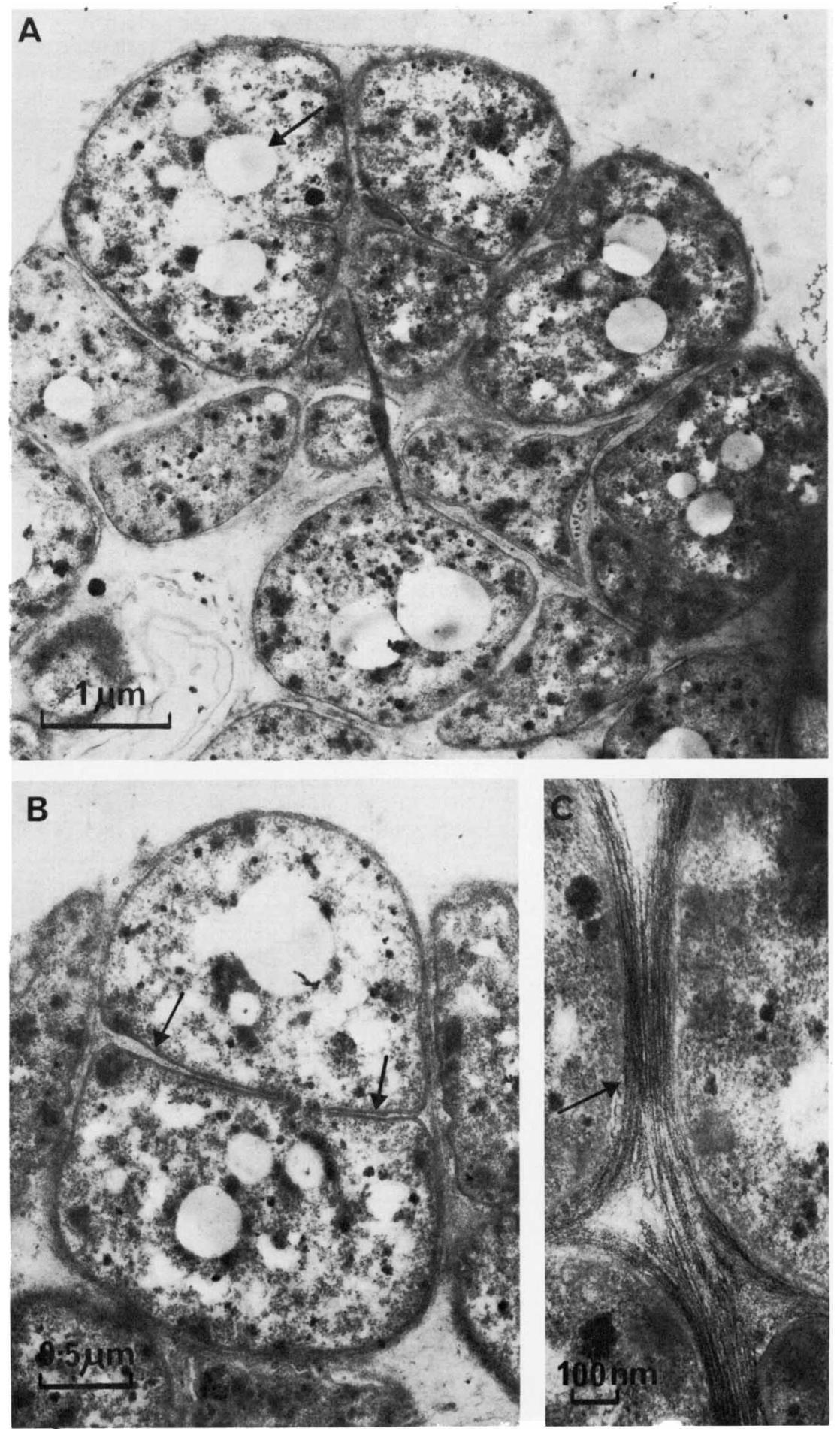

FIG. 3. Electron photomicrographs of transverse ultrathin sections of conglomerates of $C$. largomobilis strain UQM 2042 ${ }^{\mathrm{T}}$. (A) Multiplanar centripetal cell wall development and poly- $\beta$-hydroxybutyrate inclusions (arrow). (B) Magnified view of cell wall development (arrows). (C) Magnified view of laminated layers (arrow) of acidic polysaccharide stained by ruthenium red. 
early stage and budding from single cells was evident, particularly at the edges of the colonies. There was no evidence of the excessive production of fluid which characterizes our isolates. When microcolonies were disturbed with a microloop, the cells were actively motile. When grown on LWSA containing $2 \% \mathrm{NaCl}, B$. aggregatus produced highly refractile aggregates similar to those of our isolates but generally much smaller in size.

\section{DISCUSSION}

A new genus, Conglomeromonas gen. nov., is proposed for our isolates. The alternate growth forms of the isolates described above bear gross morphological similarities to growth forms observed in strains of species of the gram-positive genera Dermatophilus, Geodermatophilus (12), and Blastococcus (1). In all of these organisms, multicellular aggregates arise by multiplanar septation. However, there are fundamental differences. Conglomeromonas sp. is gram negative, as indicated by staining, electron microscopy, rapid lysis by sodium lauryl sulfate, and the presence of aminopeptidase. This organism does not exhibit any filamentous structures arising from the germination of motile cells, nor is there any evidence of budding, as described for Blastococcus (1) and Geodermatophilus (9). Conglomeromonas $\mathrm{sp}$. can be maintained under suitable nutritional conditions in either the unicellular motile phase or the multicellular phase.

Nutritionally, Conglomeromonas is less fastidious than G. obscurus and does not require yeast extract for growth. The motile cells also show differences in flagellation. Each cell of $G$. obscurus has a polar tuft of one to four flagella, whereas each cell of $B$. aggregatus has a single polar flagellum. Conglomeromonas sp. has cells with mixed flagellation, with a polar flagellum and 1 to 10 distinctive lateral flagella. The latter are easily distinguished from the polar flagellum by differences in thickness and wavelength.

There is a similarity in the ranges of guanineplus-cytosine $(\mathrm{G}+\mathrm{C})$ contents of Conglomeromonas sp. and G. obscurus DNAs (67.2 to 70.3 and 72.9 to $74.6 \mathrm{~mol} \%$, respectively) (15). Substantially lower values ( 57.4 to $58.7 \mathrm{~mol} \%$ ) have been reported for $D$. congolensis DNA (15). There has been no report on the $\mathrm{G}+\mathrm{C}$ content of Blastococcus DNA.

The multicellular conglomerate phase of Conglomeromonas also resembles that of $M$. cerebrosus, except that this recently described (11) gram-negative organism does not exhibit a motile unicellular phase of its spherical units and the $\mathrm{G}+\mathrm{C}$ content of $M$. cerebrosus DNA is 52.3 mol\%.

Unlike Dermatophilus, Geodermatophilus, and Morococcus, the transition of Conglomeromonas from the unicellular phase to the multicellular conglomerate phase appears to be influenced by sodium ions. Our experimental results indicate that this may be a specific metal ion effect, as conglomerate formation is enhanced by the presence of and concentration of sodium ions but not by lithium, potassium, calcium, or magnesium ions. Water activity does not appear to play a role. Blastococcus was also stimulated to form its conglomerate state by sodium chloride.

There are some biochemical and physiological similarities between Conglomeromonas $\mathrm{sp}$. and Aeromonas species and Plesiomonas shigelloides, but cultures of Aeromonas hydrophila and $P$. shigelloides failed to exhibit a multicellular growth phase when they were grown under the same conditions. Furthermore, the reported values of 54.2 to 61.5 and $51 \mathrm{~mol} \% \mathrm{G}+\mathrm{C}$ for the DNAs of Aeromonas species (14) and P. shigelloides (16), respectively, are substantially lower than the values for the organism described here.

Although there are some striking similarities, there are a number of fundamental characteristics which exclude the organism described here from the genera Geodermatophilus and Blastococcus. First, the Gram stain reactions are different. The gram-negative nature of the cell wall of our isolates is supported by the ease of disruption by sodium lauryl sulfate during DNA purification and also by the presence in these cells of aminopeptidase, which is characteristic of gram-negative cells (2). Second, the other fundamental characteristic which must be considered is the manner by which the motile cells are formed. In Blastococcus (1) the motile cells are produced by budding, and in Geodermatophilus the motile cells are released by budding or from a thallus. In both cases the mother cell remains nonmotile.

In the organism described here, all of the cells in the conglomerate become motile when the conglomerate dissociates, and there is no evidence of a mother-daughter relationship in which the immotile mother cell debris remains, as in Blastococcus and Geodermatophilus.

We do not regard the change in morphoform of our isolates as a cyclic growth phenomenon but rather as an environmental response. On the basis of the evidence which we describe above, we do not think that it would be appropriate to emend the description of Blastococcus or Geodermatophilus to include gram-negative organisms with a different mode of reproduction.

A new genus, Conglomeromonas gen. nov. (Con. glom. e. ro. mónas, L. pp. conglomeratus to form in a [rounded] mass; Gr. fem. n. monas a unit, monad; M. L. fem. n. Conglomeromonas monad forming in a [rounded] mass), is proposed to incorporate the strains of this organism 
and is described as follows: gram-negative, nonsporing organisms which exhibit unicellular and multicellular phases of growth. Unicellular phase cells are rod shaped, with rounded or tapered ends and a straight or slightly curved axis; cells are arranged singly or in pairs. Motile cells have mixed flagellation, with a single polar flagellum and one or more distinctive lateral flagella of different thickness and wavelength.

Multicellular conglomerates arise from single cells which lose motility, become optically refractile, and reproduce by multiplanar septation. Under suitable conditions conglomerates dissociate into single motile cells which produce water-clear colonies in which the sparse number of cells move in a sluggish manner. No filamentous structures are observed, and no buds are produced.

The organism is an obligate chemoorganotroph and a facultative anaerobe. Carbohydrate metabolism is fermentative.

The type species is Conglomeromonas largomobilis sp. nov. (lar. go. móbi. lis, L. adj. largus in a very slow manner [musical]; L. v. mobilis to move; M. L. adj. largomobilis moving in a very slow manner). The type strain is strain UQM $2041^{\mathrm{T}}$.

Conglomeromonas largomobilis gen. nov., sp. nov. The description is as for the genus, with the following additional characteristics. Colonies grown on LWA for $72 \mathrm{~h}$ at $28^{\circ} \mathrm{C}$ are 1 to $2 \mathrm{~mm}$ in diameter, colorless, translucent, low convex, and round with an entire edge and smooth surface, and they readily coalesce. Each colony contains relatively few cells. The intracellular matrix is water clear and of low viscosity. The cells are mainly in the unicellular phase and may be motile, but some multicellular conglomerate forms may be produced, particularly when colonies are well separated and the agar surface is well dried. On media containing sodium ions, the colonies are composed almost entirely of one or more conglomerates. Conglomerates are usually the same diameter as the colonies of the unicellular forms, but occasionally are larger. They are colorless, opaque, raised, and round with a rough furrowed surface and irregular edge. Conglomerates have a dry appearance, are movable intact, and are difficult to emulsify.

The optimal growth temperature is $28^{\circ} \mathrm{C}$. Growth occurs on LWA, PYEA, $0.1 \%$ peptone agar, glucose-ammonium sulfate agar, and citrate-ammonium sulfate agar. No growth occurs in phenol- and alkylamine-mineral salts media or in nitrogen-free media. Slower growth occurs in the presence of $2 \% \mathrm{NaCl}$ but is always in the conglomerate form and is pale pink in color. Growth is inhibited by $5 \% \mathrm{NaCl}$.

Catalase, oxidase, aminopeptidase, phosphatase, deoxyribonuclease, and urease are produced. Nitrate is reduced to nitrite. Citrate and malonate are utilized. Iron is deposited on ferric ammonium citrate agar. Starch and Tween 80 are hydrolyzed. Chitin, alginate, cellulose, gelatin, tributyrin, and casein are not hydrolyzed. Esculin may be hydrolyzed. Horse erythrocytes are not hemolyzed. Phenylalanine deaminase, arginine dihydrolase, indole, and $\mathrm{H}_{2} \mathrm{~S}$ are not produced. Carrot plugs are not digested. Inspissated serum is not liquefied. Ethanol and gluconate are not oxidized.

The methyl red reaction is late and weak, and the Voges-Proskauer test is negative. Acid (but no gas) is produced in Hayward fermentation medium from galactose, glucose, mannitol, and melibiose. No acid is produced from adonitol, amygdalin, D-arabinose, arabitol, dextrin, dulcitol, erythritol, ethanol, fructose, inulin, maltose, melezitose, raffinose, D-ribose, salicin, L-sorbose, starch, sucrose, trehalose, or xylose.

Acid may be produced from glycerol, sorbitol, cellobiose, mannose, rhamnose, inositol, and lactose.

The type strain is strain UQM $2041^{\mathrm{T}}$.

Two subspecies are proposed, and these may be differentiated by the characteristics described below.

C. largomobilis subsp. largomobilis subsp. nov. Colonies grown on PYEA are $2 \mathrm{~mm}$ in diameter after $72 \mathrm{~h}$ of incubation at $28^{\circ} \mathrm{C}$, cream to buff in color, opaque, low convex, and round with an entire edge and smooth surface. Growth is mucoid and easily emulsified. Cells grown on PYEA are 0.75 to 1 by 3 to $4.5 \mu \mathrm{m}$; cells grown on LWA are 1 to 1.5 by 3 to $4.5 \mu \mathrm{m}$. Cells are noncapsulated. Ageing cells contain poly- $\beta$-hydroxybutyrate inclusions. The growth temperature range is 14 to $43.5^{\circ} \mathrm{C}$. Esculin is hydrolyzed. Catalase and phosphatase activities are weak. Acid is produced from mannose, rhamnose, inositol, and lactose. The $\mathrm{G}+\mathrm{C}$ contents of the DNAs of strains UQM 2041 ${ }^{\mathrm{T}}$ and UQM 2043 are $70.2 \pm 0.6 \mathrm{~mol} \%$, as determined by the thermal denaturation method. The type strain is strain UQM $2041^{\mathrm{T}}$, which was isolated from freshwater.

C. largomobilis subsp. parooensis subsp. nov. (pa. roo. énsis, belonging to the Paroo, referring to the Paroo Channel in southwest Queensland, Australia, the source of the water from which the organism was isolated).

Separated colonies grown on PYEA are always in the conglomerate form. Growth after 72 $\mathrm{h}$ of incubation at $28^{\circ} \mathrm{C}$ is apricot colored, opaque, raised, and round with a rough furrowed surface and irregular edge. Conglomerates have a dry appearance, are movable intact, and are difficult to emulsify. Confluent growth containing single cells may be mucoid and is easily emulsified. Cells grown on PYEA are 1 to 1.5 by $1.5 \mu \mathrm{m}$; cells grown on LWA are 1 to 1.5 by 2 to $3 \mu \mathrm{m}$, but occasionally cells are 1.5 to 
2.25 by $4.5 \mu \mathrm{m}$. Cells are noncapsulated. Ageing cells contain poly- $\beta$-hydroxybutyrate inclusions. The growth temperature range is 10 to $37^{\circ} \mathrm{C}$. Esculin is not hydrolyzed. Catalase and phosphatase activities are strong. No acid is produced from glycerol or sorbitol. Acid is produced from cellobiose, mannose, rhamnose, inositol, and lactose. The $\mathrm{G}+\mathrm{C}$ content of the DNA of the type strain is $67.2 \pm 0.8 \mathrm{~mol} \%$, as determined by the thermal denaturation method. The type strain is strain UQM $2042^{\mathrm{T}}$, which was isolated from freshwater.

\section{ACKNOWLEDGMENTS}

We thank Jane Westcott and Tricia Kettlewell for assistance with the electron microscopy and Gerda Wolff for assistance with medium preparation.

\section{LITERATURE CITED}

1. Ahrens, R., and G. Moll. 1970. Ein neues knospendes Bakterium aus der Ostsee. Arch. Mikrobiol. 70:243-265.

2. Cerny, G. 1976. Method for the distinction of gramnegative from gram-positive bacteria. Eur. J. Appl. Microbiol. 3:223-225.

3. Duguid, J. P. 1975. Staining methods, p. 43-45. In Cruickshank, R., J. P. Duguid, B. P. Marmion, and R. H. A. Swain (ed.), Medical microbiology, vol. 2. The practice of medical microbiology, 12th ed. Churchill Livingstone, Edinburgh.

4. Forsyth, W. G. C., A. C. Hayward, and J. B. Roberts. 1958 . Occurrence of poly- $\beta$-hydroxybutyric acid in aerobic gram-negative bacteria. Nature (London) 182:800801.

5. Franzmann, P. D., and V. B. D. Skerman. 1981. Agitococcus lubricus gen. nov., sp. nov., a lipolytic, twitching coccus from freshwater. Int. J. Syst. Bacteriol. 31:177183.

6. Haynes, W. C. 1951. Pseudomonas aeruginosa-its characterization and identification. J. Gen. Microbiol. 5:939950.

7. Hayward, A. C. 1964 . Characteristics of Pseudomonas solanacearum. J. Appl. Bacteriol. 27:265-277.

8. Holding, A. J., and J. G. Collee. 1971. Routine biochemical tests, p. 1-33. In J. R. Norris and D. W. Ribbons (ed.),
Methods in microbiology, vol. 6A. Academic Press, Inc., New York.

9. Ishiguro, E. E., and R. S. Wolfe. 1970. Control of morphogenesis in Geodermatophilus: ultrastructural studies. J. Bacteriol. 104:566-580.

10. Kovacs, N. 1956. Identification of Pseudomonas pyocyanea by the oxidase reaction. Nature (London) 178:703.

11. Long, P. A., L. I. Sly, A. V. Pham, and G. H. G. Davis. 1981. Characterization of Morococcus cerebrosus gen. nov., sp. nov. and comparison with Neisseria mucosa. Int. J. Syst. Bacteriol. 31:294-301.

12. Luedemann, G. M. 1968. Geodermatophilus, a new genus of the Dermatophilaceae (Actinomycetales). J. Bacteriol. 96:1848-1858.

13. Luft, J. H. 1971. Ruthenium red and violet. I. Chemistry, purification, methods of use for electron microscopy and mechanism of action. Anat. Rec. 171:347-368.

14. Normore, W. M. 1976. Guanine-plus-cytosine (GC) composition of the DNA of bacteria, fungi, algae and protozoa, p. 65-235. In G. D. Fasman (ed.), Handbook of biochemistry and molecular biology, 3rd ed., vol. 2 . Nucleic acids. CRC Press, Cleveland.

15. Samsonoff, W. A., M. A. Detlefson, A. F. Fonseca, and M. R. Edwards. 1977. Deoxyribonucleic acid base composition of Dermatophilus congolensis and Geodermatophilus obscurus. Int. J. Syst. Bacteriol. 27:22-25.

16. Schubert, R. H. W. 1974. Genus Plesiomonas Habs and Schubert 1962, p. 348-349. In R. E. Buchanan and N. E. Gibbons (ed.), Bergey's manual of determinative bacteriology, 8th ed. The Williams \& Wilkins Co., Baltimore.

17. Scott, W. J. 1956. Water relations of food spoilage microorganisms. Adv. Food Res. 7:83-127.

18. Sierra, G. 1957. A simple method for the detection of lypolytic activity of microorganisms and some observations on the influence of the contact between cells and fatty substrates. Antonie van Leeuwenhoek J. Microbiol. Serol. 23:15-22.

19. Skerman, V. B. D. 1967. A guide to the identification of the genera of bacteria, 2 nd ed. The Williams \& Wilkins Co., Baltimore.

20. Skerman, V. B. D. 1968. A new type of micromanipulator. J. Gen. Microbiol. 54:287-298.

21. Sneath, P. H. A. 1956. Cultural and biochemical characteristics of the genus Chromobacterium. J. Gen. Microbiol. 15:70-98.

22. Thornley, M. J. 1960. The differentiation of Pseudomonas from other gram-negative bacteria on the basis of arginine metabolism. J. Appl. Bacteriol. 23:37-52. 